\title{
Human and animal wastes: Implications for atmospheric N2O and NOx
}

\section{Citation}

McElroy, Michael B., and Yuxuan X. Wang. 2005. " Human and Animal Wastes: Implications for Atmospheric N2O and NOx." Global Biogeochemical Cycles 19 (2) (April 15). doi:10.1029/2004gb002429.

\section{Published Version}

doi:10.1029/2004GB002429

\section{Permanent link}

http://nrs.harvard.edu/urn-3:HUL.InstRepos:28343615

\section{Terms of Use}

This article was downloaded from Harvard University's DASH repository, and is made available under the terms and conditions applicable to Other Posted Material, as set forth at http:// nrs.harvard.edu/urn-3:HUL.InstRepos:dash.current.terms-of-use\#LAA

\section{Share Your Story}

The Harvard community has made this article openly available.

Please share how this access benefits you. Submit a story.

Accessibility 


\title{
Human and animal wastes: Implications for atmospheric $\mathrm{N}_{2} \mathrm{O}$ and $\mathrm{NO}_{\mathrm{x}}$
}

\author{
Michael B. McElroy and Yuxuan X. Wang \\ Department of Earth and Planetary Sciences, Division of Engineering and Applied Sciences, Harvard University, Cambridge,
} Massachusetts, USA

Received 10 December 2004; revised 4 February 2005; accepted 16 February 2005; published 15 April 2005.

[1] More than $220 \mathrm{Tg} \mathrm{N}$ are processed annually through the global agriculture/animal/ human food chain. It is suggested that aerobic denitrification, reduction of nitrite formed in the first stage of nitrification, is an important source not only of global $\mathrm{N}_{2} \mathrm{O}$ but also of $\mathrm{NO}_{\mathrm{x}}$. A simple top-down method indicates a globally averaged yield of $2 \%$ for $\mathrm{N}_{2} \mathrm{O}$ emitted as a consequence of human disturbances to the global nitrogen cycle. This yield can account not only for the contemporary budget of atmospheric $\mathrm{N}_{2} \mathrm{O}$ but also for trends observed over the past 1000 years. The associated microbial source of $\mathrm{NO}_{\mathrm{x}}$ is estimated assuming a $\mathrm{NO}_{\mathrm{x}} / \mathrm{N}_{2} \mathrm{O}$ ratio of 3 , consistent with results from a variety of laboratory and field studies. This source is significant, particularly for large developing countries such as China and India for which its contribution is comparable to that from fossil fuel.

Citation: McElroy, M. B., and Y. X. Wang (2005), Human and animal wastes: Implications for atmospheric $\mathrm{N}_{2} \mathrm{O}$ and $\mathrm{NO}_{\mathrm{x}}$, Global Biogeochem. Cycles, 19, GB2008, doi:10.1029/2004GB002429.

\section{Introduction}

[2] World population is now 6.4 billion, projected to rise to more than 8 billion over the next 25 years [United Nations, 2003]. As we shall show, our species is responsible for mobilization of more than $220 \mathrm{TgN} \mathrm{yr}^{-1}$ today of which approximately $25 \mathrm{TgN} \mathrm{yr}^{-1}$ are ingested directly by humans with $120 \mathrm{TgN} \mathrm{yr}^{-1}$ processed by domestic animals and an additional $82 \mathrm{TgN} \mathrm{yr}^{-1}$ introduced to the environment in the form of chemical fertilizer. The inexorable rise in the abundance of atmospheric $\mathrm{N}_{2} \mathrm{O}$ attests to the importance of the human influence on the global nitrogen cycle. We shall argue that bacterially mediated oxidation of ammonium processed through the agriculture/animal/human food chain is a major source not only of global $\mathrm{N}_{2} \mathrm{O}$ but also of $\mathrm{NO}_{\mathrm{x}}$. The $\mathrm{NO}_{\mathrm{x}}$ source is particularly significant for developing countries, comparable in magnitude to the source from fossil fuel combustion for China and India.

[3] This $\mathrm{NO}_{\mathrm{x}}$ source, we shall argue, is large enough to resolve the discrepancy between bottom-up estimates for emissions of $\mathrm{NO}_{\mathrm{x}}$ from China reported by Streets et al. [2003] and values derived on the basis of inverse, top-down, methods by Wang et al. [2004a]. Streets et al. [2003] using the bottom-up approach, calculated a source of $\mathrm{NO}_{\mathrm{x}}$ in 2000 for China of $3.3 \mathrm{TgN} \mathrm{yr}^{-1}$, contributed mainly by combustion of fossil and biofuels. Wang et al. [2004a] used a nested grid version of a global chemical transport model to analyze observations of $\mathrm{CO}$ and $\mathrm{NO}_{\mathrm{y}}$ from a series of aircraft missions conducted over the western Pacific during the

Copyright 2005 by the American Geophysical Union. 0886-6236/05/2004GB002429 spring of 2001 [Jacob et al., 2003], in conjunction with ground based measurements from two stations in China, Hong Kong [Wang et al., 2003], and Lin An [Wang et al., 2004b]. Employing an optimal estimation inverse model, they concluded that emissions of $\mathrm{CO}$ and $\mathrm{NO}_{\mathrm{x}}$ were underestimated in the Streets et al. [2003] inventory by $75 \%$ and 189\%, respectively, for Central China [Wang et al., 2004a]. The discrepancy for $\mathrm{CO}$ has since been attributed to neglect of specific industrial sources in the original Streets et al. inventory (D. G. Streets et al., Revisiting China's CO emissions after TRACE-P: Synthesis of inventories, atmospheric modeling, and observations, manuscript in preparation, 2005). The discrepancy for $\mathrm{NO}_{\mathrm{x}}$, however, cannot be resolved by any reasonable adjustment of combustion sources given constraints imposed by simultaneous measurements of $\mathrm{CO}$ and $\mathrm{NO}_{\mathrm{y}}$.

[4] A brief review of in situ and laboratory studies of microbial processes contributing to emissions of $\mathrm{N}_{2} \mathrm{O}$ and $\mathrm{NO}_{\mathrm{x}}$ is presented in section 2. Emissions of $\mathrm{N}_{2} \mathrm{O}$ and $\mathrm{NO}_{\mathrm{x}}$ associated with the agriculture/animal/human food chain are evaluated in section 3 . We show that we can account for the contemporary rise in the abundance of atmospheric $\mathrm{N}_{2} \mathrm{O}$ if $2 \%$ of nitrogen involved in this chain is converted to $\mathrm{N}_{2} \mathrm{O}$. Assuming a yield of $6 \%$ for conversion of $\mathrm{N}$ to $\mathrm{NO}_{\mathrm{x}}$, consistent with the laboratory and field data, we show that we can resolve the discrepancy between top-down and bottom-up estimates for emissions of $\mathrm{NO}_{\mathrm{x}}$ from China highlighted by Wang et al. [2004a]. Trends in $\mathrm{N}_{2} \mathrm{O}$ observed over the past 1000 years are discussed in section 4. Assuming a yield for conversion of $\mathrm{N}$ to $\mathrm{N}_{2} \mathrm{O}$ identical to that adopted for the analysis of the contemporary budget, we show that we can account also for the long-term rise in 
$\mathrm{N}_{2} \mathrm{O}$ observed over the past 300 years. This lends support to the validity of the simple approach adopted here. Summary remarks are presented in section 5 .

\section{Microbial Processes}

[5] $\mathrm{N}_{2} \mathrm{O}$ and $\mathrm{NO}_{\mathrm{x}}$ (mainly $\mathrm{NO}$ ) are produced both by nitrification and denitrification. The weight of the evidence suggests that nitrification dominates emissions of $\mathrm{N}_{2} \mathrm{O}$ both for natural and perturbed environments. Elkins et al. [1978], using measurements of dissolved $\mathrm{N}_{2} \mathrm{O}$ and $\mathrm{O}_{2}$, inferred a yield of $0.3 \% \mathrm{~N}$ for $\mathrm{N}_{2} \mathrm{O}\left(\mathrm{mol} \mathrm{N}-\mathrm{N}_{2} \mathrm{O}\right.$ per mol N-NH$\left.H_{4}^{+}\right)$ produced by nitrification in the ocean under conditions where $\mathrm{O}_{2}$ was close to equilibrium with the atmosphere. A similar yield was observed under high flow, high $\mathrm{O}_{2}$, conditions in 1978 for a region of the Potomac River receiving large concentrations of $\mathrm{N}$ as $\mathrm{NH}_{4}^{+}$from the sewage treatment plant at Blue Plains [McElroy et al., 1978]. In 1977, when flow rates were significantly lower and levels of $\mathrm{O}_{2}$ notably depressed, the yield of $\mathrm{N}_{2} \mathrm{O}$ was much higher, approaching 5\% [McElroy et al., 1978]. The increase in production of $\mathrm{N}_{2} \mathrm{O}$ by nitrifying organisms at low $\mathrm{O}_{2}$ inferred from the Potomac data was confirmed subsequently by laboratory studies involving pure cultures of marine nitrifying bacteria. Goreau et al. [1980] measured a yield of $\mathrm{N}_{2} \mathrm{O}$ of $0.3 \%$ at high $\mathrm{O}_{2}$, rising to $10 \%$ when the concentration of $\mathrm{O}_{2}$ was reduced to $0.5 \%$. Lipschultz et al. [1981], studying cultures of the soil bacterium N. europaea, found evidence for production of not only $\mathrm{N}_{2} \mathrm{O}$ but also $\mathrm{NO}$ during nitrification. Sources of both $\mathrm{N}_{2} \mathrm{O}$ and $\mathrm{NO}$ increased at lower levels of $\mathrm{O}_{2}$ with the ratio $\mathrm{NO}$ to $\mathrm{N}_{2} \mathrm{O}$ (mol N to mol N) rising from $1.15 \pm 0.15$ to $5.1 \pm 3$ as the concentration of $\mathrm{O}_{2}$ was reduced from $21 \%$ to $0.5 \%(\mathrm{v} / \mathrm{v})$. Denitrification (reduction of $\mathrm{NO}_{3}^{-}$) can also contribute to production of $\mathrm{N}_{2} \mathrm{O}$. Net release to the atmosphere by this process is most likely minor, however, limited by the fact that denitrification can represent both a source and sink for $\mathrm{N}_{2} \mathrm{O}$. Elkins et al. [1978] observed high concentrations of $\mathrm{N}_{2} \mathrm{O}$ in waters on the periphery of the anoxic zone associated with the major upwelling system in the eastern tropical Pacific off the coast of Peru. The concentration of $\mathrm{N}_{2} \mathrm{O}$ was observed to drop to zero in the core of the anoxic zone. The principle end product of denitrification is $\mathrm{N}_{2}$ rather than $\mathrm{N}_{2} \mathrm{O}$. Under conditions where $\mathrm{N}_{2} \mathrm{O}$ may be produced by denitrification, it can also be consumed and net release to the atmosphere is most likely small in this case compared with the source from nitrification.

[6] The first stage of nitrification involves oxidation of $\mathrm{NH}_{4}^{+}$to $\mathrm{NO}_{2}^{-}$with $\mathrm{NH}_{2} \mathrm{OH}$ formed as an intermediate. Remde and Conrad [1990] and Anderson et al. [1993] showed that $\mathrm{N}_{2} \mathrm{O}$ and $\mathrm{NO}$ are produced by reduction of $\mathrm{NO}_{2}^{-}$rather than as intermediates in the oxidation of either $\mathrm{NH}_{4}^{+}$or $\mathrm{NH}_{2} \mathrm{OH}$, a process referred to as aerobic denitrification (or nitrifier denitrification) [Colliver and Stephenson, 2000; Wrage et al., 2001]. Bock et al. [1995], studying batch cultures of $N$. europaea and $N$. eutropha, demonstrated that both isolates use $\mathrm{NH}_{4}^{+}$as an electron donor and that either $\mathrm{O}_{2}$ or $\mathrm{NO}_{2}^{-}$may be employed as an electron acceptor. The importance of $\mathrm{NO}_{2}^{-}$in this context was shown to increase with reduction in $\mathrm{O}_{2}$, providing a ready explanation for the enhanced yields of $\mathrm{N}_{2} \mathrm{O}$ and $\mathrm{NO}$ observed at low levels of $\mathrm{O}_{2}$ [Goreau et al., 1980; Lipschultz et al., 1981]. The ratio of $\mathrm{NO}$ to $\mathrm{N}_{2} \mathrm{O}$ (mole $\mathrm{N} /$ mole $\mathrm{N}$ ) is typically greater than 1 for aerobic denitrification and increases with decreasing levels of $\mathrm{O}_{2}$, ranging from 1.15 to as high as 100 [Lipschultz et al., 1981; Remde and Conrad, 1990; Anderson and Levine, 1986; Kester et al., 1997].

\section{Top-Down Budget of $\mathrm{N}_{\mathbf{2}} \mathrm{O}$ and $\mathrm{NO}_{\mathbf{x}}$}

[7] The concentration of atmospheric $\mathrm{N}_{2} \mathrm{O}$ has risen over the past several centuries from about $270 \mathrm{ppb}$ to $314 \mathrm{ppb}$ [Butler et al., 1998]. Photolytic processes in the stratosphere provide the major sink for $\mathrm{N}_{2} \mathrm{O}$ and the loss rate, corresponding to a lifetime of about 120 years, can be defined with considerable confidence [Volk et al., 1997]. Assuming a steady state balance of production and loss of $\mathrm{N}_{2} \mathrm{O}$ in the pre-anthropogenic environment since the last interglacial period, as suggested by the ice core measurements [Sowers, 2001], the pre-anthropogenic source is

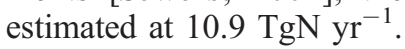

[8] Accounting for the observed contemporary increase in the abundance of atmospheric $\mathrm{N}_{2} \mathrm{O}\left(3.9 \pm 0.9 \mathrm{TgN} \mathrm{yr}^{-1}\right)$ [Butler et al., 1998] and the enhanced rate for removal at the higher concentrations of the gas prevailing today

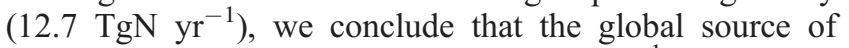
$\mathrm{N}_{2} \mathrm{O}$ has risen now to a level of $16.6{\mathrm{TgN} \mathrm{yr}^{-1}}^{-1}$, an increase in emissions over the pre-anthropogenic background by as much as $52 \%$ or $5.7 \mathrm{Tg} \mathrm{N} \mathrm{yr}^{-1}$. A relatively small fraction of the additional $\mathrm{N}_{2} \mathrm{O}$ can be attributed to industrial processes, about $1.3 \pm 0.5 \mathrm{TgN} \mathrm{yr}^{-1}$ [Intergovernmental Panel on Climate Change (IPCC), 2001]. The balance, $4.4 \mathrm{TgN} \mathrm{yr}^{-1}$, is due most likely to bacterially mediated processes associated with disposal of $\mathrm{N}$ mobilized through the agriculture/animal/human food chain.

[9] The IPCC [1997] [see also Mosier et al., 1998] presented a detailed empirical methodology that could be employed to estimate agricultural emissions of $\mathrm{N}_{2} \mathrm{O}$. Their approach distinguishes between direct (induced by $\mathrm{N}$ input) and indirect (caused by leaching and running off of $\mathrm{N}$ ) emissions of $\mathrm{N}_{2} \mathrm{O}$ and suggests "default" yields for $\mathrm{N}_{2} \mathrm{O}$ associated with various types of $\mathrm{N}$ inputs (e.g., synthesis fertilizer versus animal manures) and different animal waste management systems (e.g., anaerobic lagoon versus pasture range). Alternatively, process-oriented agroecosystems models driven by various basic environmental factors (such as temperature, soil moisture, $\mathrm{pH}$, etc.) have been employed to simulate the nitrogen cycle and generate yield data [ $\mathrm{Li}$ et al., 1992; Schmid et al., 2001]. The discrepancy between the two approaches [Li et al., 1996, 2001; Schmid et al., 2001] raises questions as to whether emission factors are known to a precision adequate to justify the level of complexity implicit in either method. Current understanding of aerobic denitrification suggests an important sensitivity of yields of $\mathrm{N}_{2} \mathrm{O}$ and $\mathrm{NO}$ to environmental conditions, specifically to levels of ambient $\mathrm{O}_{2}$. Yields are small for distributed wastes and large for concentrated wastes. Other variables and soil characteristics must also play an important role in determining the yield [Hall et al., 1996]. To circumvent lack of yield data for most of the world, we opt 
Table 1. Sources of Nitrogen in the Agriculture/Animal/Human Food Chain for Year 2001 and Associated Emissions of $\mathrm{N}_{2} \mathrm{O}$ and $\mathrm{NO}_{\mathrm{x}}{ }^{\mathrm{a}}$

\begin{tabular}{|c|c|c|c|c|c|c|c|c|}
\hline & \multicolumn{4}{|c|}{ Nitrogen Sources, ${ }^{\mathrm{b}} \mathrm{TgN} / \mathrm{yr}$} & \multirow{2}{*}{\multicolumn{2}{|c|}{ Biological Sources of $\mathrm{N}_{2} \mathrm{O}$}} & \multirow{3}{*}{$\begin{array}{c}\text { Biological } \\
\text { Sources of } \\
\mathrm{NO}_{\mathrm{x}}, \mathrm{TgN} / \mathrm{yr} \\
\end{array}$} & \multirow{3}{*}{$\begin{array}{c}\text { Industrial } \\
\text { Sources of } \\
\mathrm{NO}_{\mathrm{x}}, \mathrm{TgN} / \mathrm{yr} \\
\end{array}$} \\
\hline & \multirow{2}{*}{$\begin{array}{l}\text { Chemical } \\
\text { Fertilizer }\end{array}$} & \multirow{2}{*}{$\begin{array}{l}\text { Human } \\
\text { Wastes } \\
\end{array}$} & \multirow{2}{*}{$\begin{array}{l}\text { Animal } \\
\text { Wastes } \\
\end{array}$} & \multirow{2}{*}{$\begin{array}{l}\text { Total } \\
\text { Nitrogen }\end{array}$} & & & & \\
\hline & & & & & $\mathrm{TgN} / \mathrm{yr}$ & $\mathrm{TgCO}_{2}$ equation $/ \mathrm{yr}$ & & \\
\hline Global & 82.3 & 24.6 & 119.5 & 226.4 & 4.53 & 2107.10 & 13.58 & 32.6 \\
\hline China & 22.4 & 5.1 & 20 & 47.5 & 0.95 & 441.89 & 2.85 & 3.3 \\
\hline India & 11.3 & 4 & 17.2 & 32.5 & 0.65 & 302.34 & 1.95 & 1.7 \\
\hline United States & 10.9 & 1.4 & 9.9 & 22.2 & 0.44 & 204.66 & 1.33 & 6.1 \\
\hline European Union & 9.1 & 1.9 & 11.2 & 22.2 & 0.44 & 204.66 & 1.33 & 2.9 \\
\hline Russia & 1.1 & 0.7 & 2.3 & 4.1 & 0.08 & 37.21 & 0.25 & 1.49 \\
\hline Australia & 1.1 & 0.1 & 4.2 & 5.4 & 0.11 & 51.17 & 0.32 & 0.5 \\
\hline Brazil & 1.6 & 0.7 & 9.7 & 12 & 0.24 & 111.63 & 0.72 & 1.2 \\
\hline Indonesia & 2 & 0.9 & 1.6 & 4.4 & 0.09 & 41.86 & 0.26 & 0.42 \\
\hline
\end{tabular}

${ }^{\mathrm{a}}$ Industrial sources of $\mathrm{NO}_{\mathrm{x}}$ associated largely with transportation and power generation are shown for comparison. The industrial sources of $\mathrm{NO}_{\mathrm{x}}$ are taken from Intergovernmental Panel on Climate Change [2001], U.S. EPA [2004], Pacific Northwest National Laboratory Center for Energy Efficiency (National inventory of energy-related emissions of greenhouse gases in Russia, 2004, available at http://www.cenef.ru/info/Climate/natinventory.pdf), Streets et al. [2003], and Gugele and Ritter [2002]. Additional emissions of $\mathrm{NO}_{\mathrm{x}}$ are associated with seasonal burning of biomass, and this source may be particularly important for India, Russia, Brazil, and Indonesia.

${ }^{\mathrm{b}}$ The quantity of $\mathrm{N}$ processed annually through human and animal wastes is evaluated as the product of populations [FAO, 2004] and per capita excretion rate for $\mathrm{N}[I P C C, 1997]$. Application rates of chemical fertilizer were taken from FAO [2004]. Refer to the text (section 3) for a detailed description of the data sources.

here for a simple, global, "top-down" approach to calculate the average yield for $\mathrm{N}_{2} \mathrm{O}$ associated with the global source of $\mathrm{N}$ mobilized through the agriculture/animal/human food chain.

[10] Human and animal sources of $\mathrm{N}$ are summarized for a number of countries and regions for 2001 in Table 1 . The quantity of $\mathrm{N}$ processed annually through human and animal wastes is evaluated as the product of populations and per capita excretion rate for N. Populations of humans and animals and fertilizer use were taken from the Food and Agricultural Organization (FAO) databases [FAO, 2004]. Excretion rates for $\mathrm{N}$ contributed by different animal types were selected based on recommendations by IPCC [1997]. Humans in the developed world consume and excrete $\mathrm{N}$ at an average rate of about $5.4 \mathrm{~kg} \mathrm{~N}$ per person per year [National Research Council Committee on Nitrate Accumulation, 1972]. For persons in the less developed world, we adopt a lower value of $4 \mathrm{~kg} \mathrm{~N}$ per person per year. The agriculture/animal/human food chain is responsible for

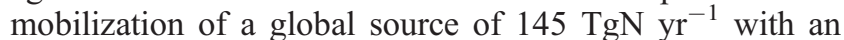
additional $82 \mathrm{TgN} \mathrm{yr}^{-1}$ introduced to the environment in the form of chemical fertilizer [FAO, 2004]. Although some portion of the $\mathrm{N}$ mobilized through human and animal wastes has come from previous applications of chemical fertilizer, the reentry of this $\mathrm{N}$ back to the soil system makes it susceptible again to microbial processes that produce $\mathrm{N}_{2} \mathrm{O}$ and $\mathrm{NO}_{\mathrm{x}}$. A breakdown of animal populations and corresponding sources of $\mathrm{N}$ for the United States, the European Union (EU) (the European Union as referenced in this paper refers to the 15 countries included in the Union in 2001 with a combined population of 378 million), China, and India is presented in Table 2. Cattle provide the dominant source of animal $\mathrm{N}$ for the United States $(74 \%$ of the total), the EU (55\%), and India (82\%). Pigs are relatively more important for China $(36 \%$ of the animal total).

[11] We can account for the magnitude of the contemporary increase in emissions of $\mathrm{N}_{2} \mathrm{O}$ by assigning a value for the average yield of $\mathrm{N}_{2} \mathrm{O}$ emitted as a consequence of the disturbance to the global nitrogen cycle associated with the agriculture/animal/human food chain. The extra (microbial)

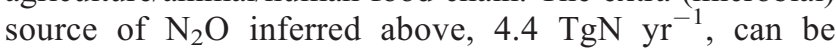
accommodated if we assume a globally averaged yield of $2 \%$ for $\mathrm{N}_{2} \mathrm{O}$ produced by oxidation of the additional $\mathrm{N}$

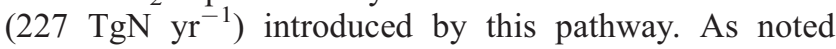
earlier, this yield is consistent with results from a variety of field and laboratory data [McElroy et al., 1978; Goreau et al., 1980; Lipschultz et al., 1981; Czepiel et al., 1996;

Table 2. Animal Populations and Corresponding Sources of Nitrogen for China, India, the United States, and the European Union in $2001^{\mathrm{a}}$

\begin{tabular}{|c|c|c|c|c|c|c|c|}
\hline Regions & Population/N Source & Cattle & Pig & Sheep and Goat & Poultry & Others & Total \\
\hline \multirow[t]{2}{*}{ China } & Population & 128 & 450 & 280 & 4611 & 22 & 5491 \\
\hline & $\mathrm{N}$ sources & 5.8 & 7.2 & 3.4 & 2.8 & 0.9 & 20.0 \\
\hline \multirow[t]{2}{*}{ India } & Population & 314 & 17 & 182 & 743 & 3 & 1259 \\
\hline & $\mathrm{N}$ sources & 14.1 & 0.3 & 2.2 & 0.4 & 0.1 & 17.2 \\
\hline \multirow[t]{2}{*}{ United States } & Population & 97 & 59 & 8 & 1993 & 5 & 2162 \\
\hline & $\mathrm{N}$ sources & 7.3 & 1.2 & 0.1 & 1.2 & 0.1 & 9.9 \\
\hline \multirow[t]{2}{*}{ European Union } & Population & 82 & 122 & 115 & 1191 & 3 & 1513 \\
\hline & $\mathrm{N}$ sources & 6.2 & 2.4 & 1.8 & 0.7 & 0.1 & 11.2 \\
\hline
\end{tabular}

${ }^{\mathrm{a}}$ Units are millions for population and $\mathrm{TgN} \mathrm{yr}^{-1}$ for $\mathrm{N}$ sources. 
Sherlock et al., 2002; Chang et al., 1998; Velthof et al., 2003], although the specific value adopted for this analysis is clearly not required by these data. As we shall see, this simple approach implies a source of $0.44 \mathrm{TgN}-\mathrm{N}_{2} \mathrm{O} \mathrm{yr}^{-1}$ for the United States, slightly larger than the value estimated following the IPCC methodology by the U.S. Environmental Protection Agency (U.S. EPA) [2004] for direct emissions associated with the application of commercial and organic fertilizer to fields in the United States $(0.33 \mathrm{TgN}$ $\mathrm{N}_{2} \mathrm{O} \mathrm{yr}^{-1}$ ) but less than the value reported for the overall contribution of U.S. agriculture to emissions of $\mathrm{N}_{2} \mathrm{O}$ $\left(0.65 \mathrm{TgN}^{-\mathrm{N}_{2}} \mathrm{O} \mathrm{yr}^{-1}\right)$. The composite EPA result accounts not only for emissions prompted directly by the application of fertilizers to agricultural systems but also for emissions stimulated more indirectly by influences such as the cultivation of legumes, the disposal of crop residues and leaching of excess $\mathrm{N}$ from soils. Under the circumstances, the agreement between the simple, global, top-down, approach adopted here and the more complex, bottom-up, procedure followed by the EPA is reassuring. Berges and Crutzen [1996], using lower and upper quartiles of measured molar emission ratios of $\mathrm{N}_{2} \mathrm{O}$ to $\mathrm{NH}_{3}$, derived the global source in the range of $0.2 \sim 2.5 \mathrm{Tg} \mathrm{N} / \mathrm{yr}$ for $\mathrm{N}_{2} \mathrm{O}$ emitted from cattle and pig manure stored in or at animal housings, corresponding to a yield of $0.5 \sim 5.4 \%$ from the total nitrogen in the manure. Their study did not account for $\mathrm{N}_{2} \mathrm{O}$ emissions from grazing cattle, goats, and sheep, and application of the manure to agricultural soils. The $2 \%$ yield for $\mathrm{N}_{2} \mathrm{O}$ adopted in our analysis lies roughly in the median of the range reached independently by Berges and Crutzen [1996] using measured ratio of $\mathrm{N}_{2} \mathrm{O}$ to $\mathrm{NH}_{3}$. Bouwman et al. [2002a, 2002b] summarized measurement data from the literature and derived an empirical relationship with the residual maximum likelihood procedure to describe the influence of environmental and management factors on $\mathrm{N}_{2} \mathrm{O}$ and $\mathrm{NO}$ emissions from agricultural soils. Measurement data were log-transformed in their analysis to reduce the effect of extreme values and data from grazing systems were excluded due to lack of information on the $\mathrm{N}$ inputs from animal excreta. Their study suggested that the global aggregated yield for fertilizer-induced emissions was only $0.9 \%$ for $\mathrm{N}_{2} \mathrm{O}$ and $0.7 \%$ for $\mathrm{NO}$, significantly lower than results obtained from our study.

[12] Estimates for the associated emissions of $\mathrm{N}_{2} \mathrm{O}$ and $\mathrm{NO}_{\mathrm{x}}$ are included in Table 1. For $\mathrm{N}_{2} \mathrm{O}$, we adopted the yield of $2 \%$ inferred from consideration of the global budget, as discussed above. For $\mathrm{NO}_{\mathrm{x}}$ we assumed a yield of $6 \%$ (i.e., $\mathrm{NO} / \mathrm{N}_{2} \mathrm{O}$ ratio of 3 ) consistent with the laboratory studies cited earlier for low oxygen conditions, in accord also with results from a variety of field studies [Clough et al., 2003; Shepherd et al., 1991; Slemr and Seiler, 1984; Gasche and Papen, 1999]. This choice was made on the grounds that $\mathrm{O}_{2}$ concentrations are likely to be low in environments receiving large inputs of concentrated animal waste and fertilizers and that they are likely also to be depressed under conditions applying to disposal of human waste in the developing world. Specifically, the yield of $6 \%$ for $\mathrm{NO}_{\mathrm{x}}$ is large enough to resolve the discrepancy between bottom-up estimates for emissions of $\mathrm{NO}_{\mathrm{x}}$ from Central China reported by Streets et al. [2003] and values derived using inverse, top-down, methods by Wang et al. [2004a]. The missing source of $\mathrm{NO}_{\mathrm{y}}$ identified by Wang et al. [2004a] for Central China was estimated at $1.1 \mathrm{TgN} \mathrm{yr}^{-1}$. Central China, as identified in their study, accounts for $30 \%$ of the Chinese population and approximately $30 \%$ of the country's domestic animals. Using the yield of $6 \%$ for $\mathrm{NO}_{\mathrm{x}}$, we would attribute a source of $0.9 \mathrm{TgN} \mathrm{yr}^{-1}$ to the agriculture/animal/ human food chain in Central China, offering a plausible resolution to the discrepancy highlighted by Wang et al. [2004a].

[13] The data in Table 1 suggest that China may be responsible for as much as $20 \%$ of the total global sources of $\mathrm{N}_{2} \mathrm{O}$ and $\mathrm{NO}_{\mathrm{x}}$ associated with processing of $\mathrm{N}$ through the agriculture/animal/human food chain with an additional $14 \%$ attributable to India. Corresponding emissions from the United States and EU are somewhat less, about $10 \%$ of the global total, reflecting the smaller human populations of these regions. The greenhouse warming potential of $\mathrm{N}_{2} \mathrm{O}$ on a per molecule basis exceeds that of $\mathrm{CO}_{2}$ by a factor of 296 [IPCC, 2001]. Combustion of fossil fuel was responsible for emission of $2794 \mathrm{Tg} \mathrm{CO}_{2}$ for China, $1072 \mathrm{Tg} \mathrm{CO}_{2}$ for India, $5606 \mathrm{Tg} \mathrm{CO}$ for the United States, and $3392 \mathrm{Tg} \mathrm{CO}_{2}$ for the EU in 2000 [Marland et al., 2003]. The results in Table 1 imply therefore that radiative forcing attributed to $\mathrm{CO}_{2}$ should be enhanced by $16 \%, 28 \%, 4 \%$, and $6 \%$ for China, India, the United States, and the EU, respectively, to allow for the additional contribution from $\mathrm{N}_{2} \mathrm{O}$.

[14] The biological source of $\mathrm{NO}_{\mathrm{x}}$ from the agriculture/ animal/human food chain is especially significant for developing countries, comparable in magnitude to the source from fossil fuel combustion for China and India. It is less important for developed regions such as the United States where contributions from fossil fuel combustion dominate. However, as efforts are made to reduce $\mathrm{NO}_{\mathrm{x}}$ emissions from combustion processes (including biomass burning) to mitigate problems associated with acid rain and ozone pollution, the biological source of $\mathrm{NO}_{\mathrm{x}}$ will inevitably grow in relative importance. Accounting for sources of $\mathrm{NO}_{\mathrm{x}}$ associated with combustion of fossil fuels, aggregated emissions of $\mathrm{NO}_{\mathrm{x}}$ from the United States and the EU in 2000-2001 amount to $7.4 \mathrm{TgN} \mathrm{yr}^{-1}$ and $4.3 \mathrm{TgN} \mathrm{yr}^{-1}$, which may be compared with emissions from China and India (including combustion sources) for which we compute values of $6 \mathrm{TgN} \mathrm{yr}^{-1}$ and $3.7 \mathrm{TgN} \mathrm{yr}^{-1}$, respectively.

[15] Estimates in the literature for the global source of $\mathrm{NO}_{\mathrm{x}}$ emitted from soils, including contributions from nonagricultural soils, range from 4 to $21 \mathrm{TgN} / \mathrm{yr}$ [Holland et al., 1999, and references therein]. Our estimate for the biological source of $\mathrm{NO}_{\mathrm{x}}$ associated with the agriculture/animal/ human food chain lies within this range but is significantly higher than values suggested by some studies [Lee et al., 1997; IPCC, 2001]. Yienger and Levy [1995], for example, using an empirical model incorporating temperature and precipitation outputs from a general circulation model, estimated a global source of $3 \mathrm{TgN} / \mathrm{yr}$ for $\mathrm{NO}_{\mathrm{x}}$ emitted from agricultural soils in the absence of vegetation cover. In the presence of vegetation cover, emission rates in this model were reduced to $2.25 \mathrm{TgN} / \mathrm{yr}$. Their analysis did not allow for contributions from animal wastes and may be expected therefore to underestimate overall emissions of 

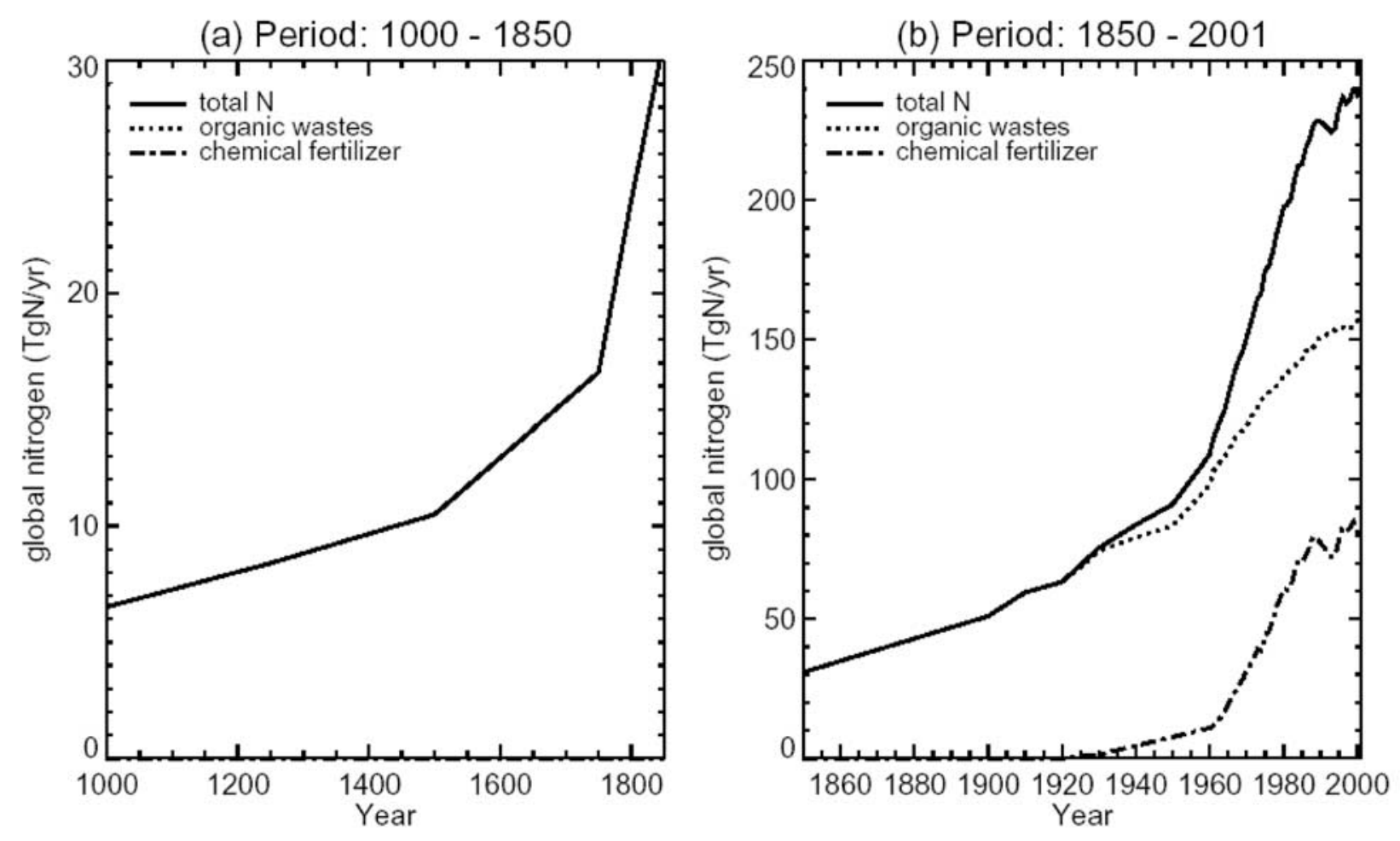

Figure 1. Amount of $\mathrm{N}$ processed through the agriculture/animal/human food chain for the periods (a) $1000-1850$ and (b) $1850-2001$.

$\mathrm{NO}_{\mathrm{x}}$. Whether applied to agricultural lands or left "as is" on fields, animal wastes are susceptible to microbial processes with potential for production of important quantities of both $\mathrm{NO}_{\mathrm{x}}$ and $\mathrm{N}_{2} \mathrm{O}$. Davidson and Kingerlee [1997], on the basis of a careful review of over 60 then-available papers reporting field measurements of soil $\mathrm{NO}_{\mathrm{x}}$ emissions, estimated a global source of $21 \mathrm{Tg} \mathrm{N} / \mathrm{yr}$ for $\mathrm{NO}_{\mathrm{x}}$ emitted from soils. Their estimate suggested that tropical savanna was the largest contributor to this global budget, responsible for a source of $7.5 \mathrm{Tg} \mathrm{N} / \mathrm{yr}$ as compared to their estimate of $5.4 \mathrm{Tg} \mathrm{N} / \mathrm{yr}$ from cultivated land. Field measurements adopted in their study suggested large variation in fertility and hence $\mathrm{NO}_{\mathrm{x}}$ emissions within the savanna biome. It is not clear whether organic wastes from animals have contributed to fertility for this biome. Galloway et al. [2004] constructed the global $\mathrm{N}$ budget for 1860 and the early 1990s. Their analysis did not evaluate the $\mathrm{N}$ mobilized by human and domestic animals as this $\mathrm{N}$ is not newly created by human activities. They estimated that agricultural soils were responsible for a global $\mathrm{NO}_{\mathrm{x}}$ source of $2.6 \mathrm{Tg} \mathrm{N}$ in 1993 with zero contribution from animal and human wastes.

\section{Trends in $\mathbf{N}_{2} \mathrm{O}$ Emissions}

[16] Trends in N processed through the global agriculture/ animal/human food chain will be evaluated here and used to reconstruct trends for $\mathrm{N}_{2} \mathrm{O}$ over the past 1000 years. Although agricultural practices began as early as $10,000 \mathrm{yr}$
B.P., the sparse spatial scale of early agriculture implies that its impact on atmospheric $\mathrm{N}_{2} \mathrm{O}$ should be minimal. As we pointed out earlier, the yield of $\mathrm{N}_{2} \mathrm{O}$ is large for concentrated wastes resulting from settled communities of humans and animals with sufficient density. Therefore we do not think the conclusions reached by Ruddiman [2003] on a much earlier impact of agriculture on $\mathrm{CO}_{2}$ and $\mathrm{CH}_{4}$ will apply to $\mathrm{N}_{2} \mathrm{O}$. The global source of $\mathrm{N}$ mobilized through the food chain between 1961 and 2001 was estimated directly using per capita annual excretion rates for humans and animals as described above adopting FAO databases [FAO, 2004] for human and animal populations and fertilizer use. For the period prior to 1961, not covered by the FAO databases, we adopted estimates of human population and fertilizer use for selected years as reported by the United Nations (UN) (The world at six billion, Table 1: World population from, 1999, available at http://www.un.org/esa/ population/publications/sixbillion/sixbilpart1.pdf) and the International Fertilizer Industry Association (Production and international trade statistics, 2004, available at http:// www.fertilizer.org/ifa/statistics/indicators/pocket_annexes. asp). Regional estimates of animal populations for the period 1850 to 1961 are taken from Mitchell [2003a, 2003b, 2003c]. Data were extrapolated linearly for years not covered by the sources listed above. Annual average per-capita excretion rates for humans were selected for different time intervals as follows: $3 \mathrm{~kg} \mathrm{~N}$ before 1800 , $3.5 \mathrm{~kg} \mathrm{~N}$ between 1800 and 1900, and $4 \mathrm{~kg} \mathrm{~N}$ after 1900 . These values were chosen somewhat arbitrarily to reflect the 


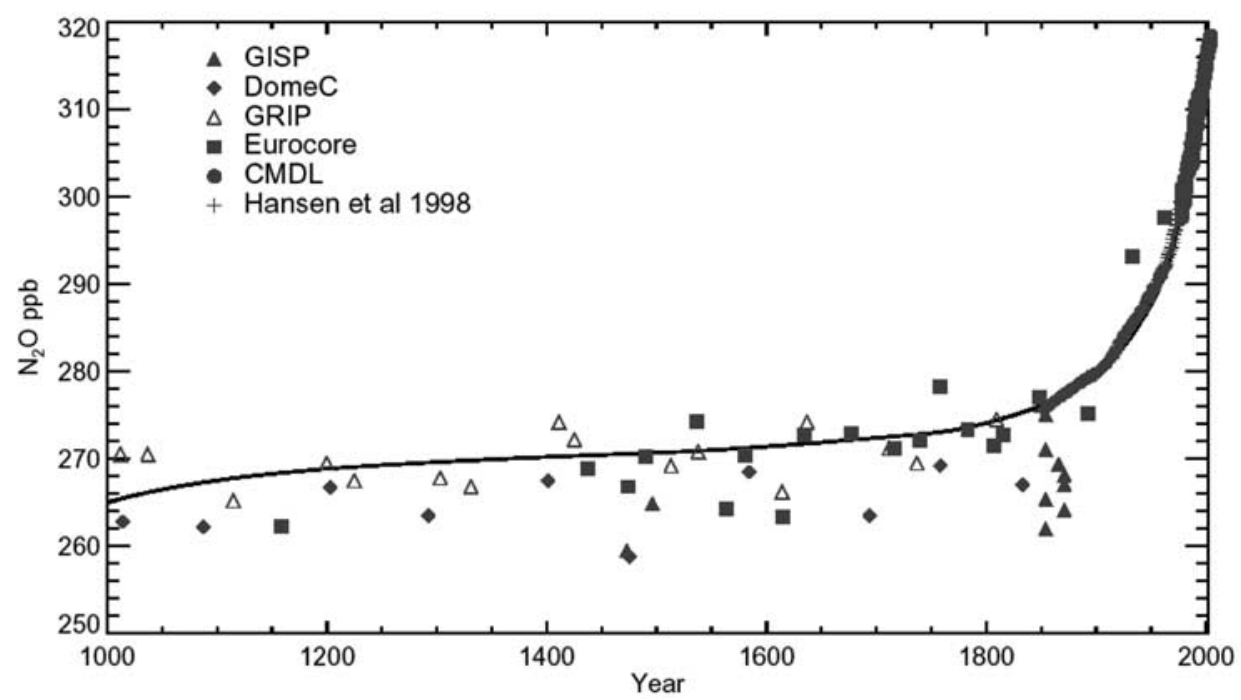

Figure 2. Comparison between observed (red symbols) and simulated (black line) atmospheric concentrations of $\mathrm{N}_{2} \mathrm{O}$ for the period 1000-2001. Observations are taken from ice core measurements from GISP II [Sowers et al., 2003], Dome C [Flückiger et al., 2002], Eurocore and GRIP [Flückiger et al., 2000], the Climate Monitoring and Diagnostics Laboratory (CMDL), and composite data set from Hansen et al. [1998]. See color version of this figure at back of this issue.

impact of the Industrial Revolution on worldwide human welfare. Excretion rates for different types of animals were scaled accordingly for the three time intervals. Lacking historical data on populations of different animal types for the period prior to 1850 , animal wastes were evaluated indirectly by scaling contributions from humans as described below. Direct evaluations of animal wastes for the period 1850-1900 indicate that the scaling factor (i.e., the ratio of $\mathrm{N}$ in animal wastes to those in human wastes) has been relatively stable, ranging from 6.5 to 7.5. We assume that the scaling factor for the period prior to 1850 is close to the lower bound of this range. Accordingly, we adopt a scaling factor of 6 for the period prior to 1850 .

[17] Figure 1 presents a summary of the contributions to $\mathrm{N}$ processed through the global agriculture/animal/human food chain as estimated here for the past 1000 years. Chemical fertilizer was significant only after 1920. The source of $\mathrm{N}$ mobilized by the global food chain increases from $6.5 \mathrm{TgN} / \mathrm{yr}$ in 1000 to $31 \mathrm{TgN} / \mathrm{yr}$ in 1850 , rising to $227 \mathrm{TgN} / \mathrm{yr}$ in 2001. Our analysis here does not include the contribution from the cultivation of legumes. The increase over the past 100 years is close to exponential. Associated emissions of $\mathrm{N}_{2} \mathrm{O}$ for the past 1000 years were estimated using the yield of $2 \%$ for $\mathrm{N}_{2} \mathrm{O}$ inferred from the contemporary global budget. Anthropogenic emissions of $\mathrm{N}_{2} \mathrm{O}$ increase from less than $0.5 \mathrm{TgN} / \mathrm{yr}$ before 1850 to $4.5 \mathrm{TgN} / \mathrm{yr}$ in 2001.

[18] Estimates of emissions were adopted to calculate concentrations of atmospheric $\mathrm{N}_{2} \mathrm{O}$ using a one-box atmospheric model [Kroeze et al., 1999],

$$
\mathrm{dC} / \mathrm{dt}=\mathrm{S} / 4.8-\mathrm{C} / \tau,
$$

where $\mathrm{C}$ defines the concentration of $\mathrm{N}_{2} \mathrm{O}(\mathrm{ppb})$, $\mathrm{t}$ is time (years), $\mathrm{S}$ defines emissions (Tg N/yr; $4.8 \mathrm{Tg} \mathrm{N}=1 \mathrm{ppbv}$
$\mathrm{N}_{2} \mathrm{O}$ ), and $\tau$ represents the lifetime for $\mathrm{N}_{2} \mathrm{O}$ (years), fixed here at 120 years. Emissions (S) allow for both natural and anthropogenic sources of $\mathrm{N}_{2} \mathrm{O}$. We assumed a time-

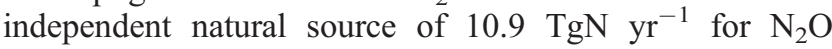
(see section 3). The industrial source of $\mathrm{N}_{2} \mathrm{O}$ reflects contributions from adipic acid and nitric acid production, fossil fuel fired power plants, and mobile combustion, adding up to about $1.3 \mathrm{TgN} \mathrm{yr}^{-1}$ in 2000 . The trend in the industrial source with time was assumed to be the same as that for fertilizer. Results are relatively insensitive to this assumption.

[19] Concentrations of $\mathrm{N}_{2} \mathrm{O}$ calculated using the one-box model are compared with observations in Figure 2. The concentration of $\mathrm{N}_{2} \mathrm{O}$ was set equal to $265 \mathrm{ppbv}$ in 1000 , as suggested by ice core measurements [Sowers et al., 2002]. Concentrations simulated for the entire period are in good agreement with observed trends, offering support for the simple approach adopted here to estimate the source of $\mathrm{N}_{2} \mathrm{O}$ associated with the agriculture/animal/ human food chain.

\section{Concluding Remarks}

[20] The agriculture/animal/human food chain processed approximately $227 \mathrm{Tg} \mathrm{N}$ in 2001, with over 50\% contributed by animals. We assumed that reduction of nitrite by nitrifying organisms under low oxygen conditions provided the dominant anthropogenic source of $\mathrm{N}_{2} \mathrm{O}$. We presented a simple, global, top-down model which implied a global average yield of $2 \%$ for $\mathrm{N}_{2} \mathrm{O}$ produced from $\mathrm{N}$ processed through the global food chain. We showed that this simple model can account not only for the contemporary budget of atmospheric $\mathrm{N}_{2} \mathrm{O}$ but also for trends observed over the past 1000 years. 
[21] Microbial reduction of $\mathrm{NO}_{2}^{-}$is responsible also for an important source of $\mathrm{NO}_{\mathrm{x}}$. We assumed a yield of $6 \%$ for $\mathrm{NO}_{\mathrm{x}}$ formed by this path, 3 times larger than that inferred for $\mathrm{N}_{2} \mathrm{O}$, consistent with both laboratory and in situ field observations under low oxygen conditions. The yield for $\mathrm{NO}_{\mathrm{x}}$ was selected specifically to resolve the discrepancy between "bottom-up" and "top-down" estimates for the source of $\mathrm{NO}_{\mathrm{x}}$ over Central China, as highlighted by Wang et al. [2004a].

[22] It is clear that further work will be required to refine our understanding of global sources of $\mathrm{N}_{2} \mathrm{O}$ and $\mathrm{NO}_{\mathrm{x}}$. The yield for $\mathrm{NO}_{\mathrm{x}}$ adopted here was selected specifically to account for observations taken in and near China over the March-April time frame in 2001. Rates for nitrification might be expected to increase with temperature. The response of $\mathrm{N}_{2} \mathrm{O}$ and $\mathrm{NO}_{\mathrm{x}}$ production to a change in temperature is however less clear. As indicated above, the yield of $\mathrm{N}_{2} \mathrm{O}$ and $\mathrm{NO}_{\mathrm{x}}$ from nitrification is expected to depend on the relative abundances of $\mathrm{NO}_{2}^{-}$and $\mathrm{O}_{2}$ for the medium in which decomposition is taking place. It is difficult to predict how this ratio should vary with temperature. Further work, both in the laboratory and field, should help clarify this issue.

[23] There can be little doubt, however, that emissions of $\mathrm{N}_{2} \mathrm{O}$ and $\mathrm{NO}_{\mathrm{x}}$ are significant both regionally and globally and that they may be expected to increase in the future. Humans have evolved from relatively passive participants on the stage of life to a position of dominance in the global nitrogen cycle, as is the case also for the carbon cycle and arguably further for $\mathrm{S}$ and $\mathrm{P}$. It is unlikely that our influence will soon be diminished.

[24] Acknowledgments. This research was supported by the V. Kann Rasmussen Foundation and the Henry Luce Foundation, as part of the China Project of the Harvard University Centre for the Environment. It was also supported by the National Science Foundation, grant ATM-0236501.

\section{References}

Anderson, I. C., and J. S. Levine (1986), Relative rates of nitric-oxide and nitrous-oxide production by nitrifiers, denitrifiers, and nitrate respirers, Appl. Environ. Microbiol., 51, 938-945.

Anderson, I. C., M. Poth, J. Homstead, and D. Burdige (1993), A comparison of $\mathrm{NO}$ and $\mathrm{N}_{2} \mathrm{O}$ production by the autotrophic nitrifier Nitrosomonas europaea and the heterotrophic nitrifier Alcaligenes faecalis, Appl. Environ. Microbiol., 59, 3523-3525.

Berges, M. G. M., and P. J. Crutzen (1996), Estimates of global $\mathrm{N}_{2} \mathrm{O}$ emissions from cattle, pig and chicken manure, including a discussion of $\mathrm{CH}_{4}$ emissions, J. Atmos. Chem., 24, 241-269.

Bock, E., I. Schmidt, R. Stuven, and D. Zart (1995), Nitrogen loss caused by nitrifying Nitrosomonas cells using ammonia or hydrogen as electron donors and nitrite as electron acceptor, Arch. Microbiol., 163, 16-20.

Bouwman, A. F., L. J. M. Boumans, and N. H. Batjes (2002a), Emissions of $\mathrm{N}_{2} \mathrm{O}$ and $\mathrm{NO}$ from fertilized fields: Summary of available measurement data, Global Biogeochem. Cycles, 16(4), 1058, doi:10.1029/ $2001 \mathrm{~GB} 001811$.

Bouwman, A. F., L. J. M. Boumans, and N. H. Batjes (2002b), Modeling global annual $\mathrm{N}_{2} \mathrm{O}$ and $\mathrm{NO}$ emissions from fertilized fields, Global Biogeochem. Cycles, 16(4), 1080, doi:10.1029/2001GB001812.

Butler, J. H., et al. (1998), Nitrous oxide and halocompounds, Summary Rep. 24, edited by D. J. Hofmann, J. T. Peterson, and R. M. Rosson, pp. 91-121, Clim. Monit. and Diag. Lab., Boulder, Colo.

Chang, C., C. M. Cho, and H. H. Janzen (1998), Nitrous oxide emission from long-term manured soils, Soil Sci. Soc. Am. J., 62(3), 677-682.

Clough, T. J., et al. (2003), Emission of nitrogen oxides and ammonia from varying rates of applied synthetic urine and correlations with soil chemistry, Aust. J. Soil Res., 41, 421-438.
Colliver, B. B., and T. Stephenson (2000), Production of nitrogen oxide and dinitrogen oxide by autotrophic nitrifiers, Biotech. Adv., 18, 219-232.

Czepiel, P., E. Douglas, R. Harriss, and P. Crill (1996), Measurements of $\mathrm{N}_{2} \mathrm{O}$ from composted organic wastes, Environ. Sci. Technol., 30, 25192525 .

Davidson, E. A., and W. Kingerlee (1997), A global inventory of nitric oxide emissions from soils, Nutr. Cycling Agroecosyst., 48, 37-50.

Elkins, J. W., S. C. Wofsy, M. B. McElroy, C. E. Kolb, and W. A. Kaplan (1978), Aquatic sources and sinks for nitrous oxide, Nature, 275, 602606.

Flückiger, J., A. Dällenbach, T. Blunier, B. Stauffer, T. F. Stocker, D. Raynaud, and J.-M. Barnola (2000), Variations in atmospheric $\mathrm{N}_{2} \mathrm{O}$ concentration during abrupt climatic changes, Science, 285, 227-230.

Flückiger, J., E. Monnin, B. Stauffer, J. Schwander, T. F. Stocker, J. Chappellaz, D. Raynaud, and J.-M. Barnola (2002), High-resolution Holocene $\mathrm{N}_{2} \mathrm{O}$ ice core record and its relationship with $\mathrm{CH}_{4}$ and $\mathrm{CO}_{2}$, Global Biogeochem. Cycles, 16(1), 1010, doi:10.1029/2001GB001417.

Food and Agriculture Organization (FAO) (2004), FAOSTAT Statistical Database, Rome. (Available at http://apps.fao.org)

Galloway, J. N., et al. (2004), Nitrogen cycles: Past, present, and future, Biogeochemistry, 70, 153-226.

Gasche, R., and H. Papen (1999), A 3-year continuous record of nitrogen trace gas fluxes from untreated and limed soil of a N-saturated spruce and beech forest ecosystem in Germany: 2. NO and $\mathrm{NO}_{2}$ fluxes, J. Geophys. Res., 104, 18,505-18,520.

Goreau, T. J., et al. (1980), Production of $\mathrm{NO}_{2}^{-}$and $\mathrm{N}_{2} \mathrm{O}$ by nitrifying bacteria at reduced concentrations of oxygen, Appl. Environ. Microbiol., 40, 526-532.

Gugele, B., and M. Ritter (2002), Annual European Community CLRTAP emission inventory 1990-2000, report, Eur. Environ. Agency, Copenhagen. (Available at http://reports.eea.eu.int/technical_report_2002_73/en)

Hall, S. J., P. A. Matson, and P. M. Roth (1996), $\mathrm{NO}_{\mathrm{x}}^{-}$emissions from soil: Implications for air quality modeling in agricultural regions, Annu. Rev. Energy Environ., 21, 311-346.

Hansen, J. E., et al. (1998), Climate forcings in the Industrial era, Proc. Natl. Acad. Sci. U. S. A., 95, 12,753-12,758.

Holland, E. A., F. J. Dentener, B. H. Braswell, and J. M. Sultzman (1999), Contemporary and pre-industrial global reactive nitrogen budgets, Biogeochemistry, 46, 7-43.

Intergovernmental Panel on Climate Change/Organization for Economic Co-operation and Development/International Energy Agency (1997), Revised 1996 IPCC Guidelines for National Greenhouse Gas Inventories, report, Org. for Econ. Co-op. and Dev., Paris.

Intergovernmental Panel on Climate Change (2001), Climate Change 2001. The Scientific Basis, edited by J. T. Houghton et al., Cambridge Univ. Press, New York.

Jacob, D. J., et al. (2003), Transport and Chemical Evolution over the Pacific (TRACE-P) aircraft mission: Design, execution, and first results, J. Geophys. Res., 108(D20), 9000, doi:10.1029/2002JD003276.

Kester, R. A., W. de Boer, and H. H. Laanbroek (1997), Production of $\mathrm{NO}$ and $\mathrm{N}_{2} \mathrm{O}$ by pure cultures of nitrifying and denitrifying bacteria during change in aeration, Appl. Environ. Microbiol., 63, $3872-$ 3877.

Kroeze, C., A. Mosier, and L. Bouwman (1999), Closing the global $\mathrm{N}_{2} \mathrm{O}$ budget: A retrospective analysis 1500-1994, Global Biogeochem. Cycles, 13, 1-8.

Lee, D. S., et al. (1997), Estimations of global $\mathrm{NO}_{\mathrm{x}}$ emissions and their uncertainties, Atmos. Environ., 31, 1735-1749.

Li, C., S. Frolking, and T. Frolking (1992), A model of nitrous oxide evolution from soil driven by rainfall events: 1 . Model structure and sensitivity, J. Geophys. Res., 97, 9759-9776.

Li, C., V. Narayanan, and R. C. Harriss (1996), Model estimates of nitrous oxide emissions from agricultural lands in the United States, Global Biogeochem. Cycles, 10, 297-306.

$\mathrm{Li}$, C., et al. (2001), Comparing a process-based agro-ecosystem model to the IPCC methodology for developing a national inventory of $\mathrm{N}_{2} \mathrm{O}$ emissions from arable lands in China, Nutr. Cycling Agroecosyst., 60, 159175 .

Lipschultz, F., et al. (1981), Production of $\mathrm{NO}$ and $\mathrm{N}_{2} \mathrm{O}$ by soil nitrifying bacteria: a source of atmospheric nitrogen oxides, Nature, 294, 641643.

Marland, G., T. A. Boden, and R. J. Andres (2003), Global, regional, and national $\mathrm{CO}_{2}$ emissions, in Trends: A Compendium of Data on Global Change, Carbon Dioxide Inf. Anal. Cent., Oak Ridge Natl. Lab., Oak Ridge, Tenn. (Available at http://cdiac.esd.ornl.gov/trends/emis/em cont.htm)

McElroy, M. B., et al. (1978), Production and release of $\mathrm{N}_{2} \mathrm{O}$ from Potomac estuary, Limnol. Oceanogr., 23(6), 1168-1182. 
Mitchell, B. R. (2003a), International Historical Statistics, the Americas: 1750-2000, 5th ed., McMillian, New York.

Mitchell, B. R. (2003b), International Historical Statistics, Africa, Asia and Oceania: $1750-2000$, 4th ed., McMillian, New York.

Mitchell, B. R. (2003c), International Historical Statistics, Europe: 17502000, 5th ed., McMillian, New York.

Mosier, A., et al. (1998), Closing the global atmospheric $\mathrm{N}_{2} \mathrm{O}$ budget: Nitrous oxide emissions through the agricultural nitrogen cycle, Nutr. Cycling Agroecosyst., 52, 225-248.

National Research Council Committee on Nitrate Accumulation (1972), Accumulation of Nitrate, Natl. Acad. of Sci., Washington, D. C.

Remde, A., and R. Conrad (1990), Production of nitric oxide in Nitrosomonas europaea by reduction of nitrite, Arch. Microbiol., 154, 187-191.

Ruddiman, W. F. (2003), The anthropogenic greenhouse era began thousands of years ago, Clim. Change, 61, 261-293.

Schmid, M., A. Neftel, M. Riedo, and J. Fuhrer (2001), Process-based modeling of nitrous oxide emissions from different nitrogen sources in mown grassland, Nutr. Cycling. Agroecosyst., 60, 177-187.

Shepherd, M. F., S. Barzetti, and D. R. Hastie (1991), The production of atmospheric $\mathrm{NO}_{\mathrm{x}}$ and $\mathrm{N}_{2} \mathrm{O}$ from a fertilized agricultural soil, Atmos. Environ., Part A, 25, 1961-1969.

Sherlock, R. R., et al. (2002), Ammonia, methane, and nitrous oxide emission from pig slurry applied to a pasture in New Zealand, J. Environ. Qual., 31, 1491-1501.

Slemr, F., and W. Seiler (1984), Field measurements of $\mathrm{NO}$ and $\mathrm{NO}_{2}$ emissions from fertilized and unfertilized soils, J. Atmos. Chem., 2, 124.

Sowers, T. (2001), $\mathrm{N}_{2} \mathrm{O}$ record spanning the penultimate deglaciation from the Vostok ice core, J. Geophys. Res., 106, 31,903-31,914.

Sowers, T., A. Rodebaugh, N. Yoshida, and S. Toyoda (2002), Extending records of the isotopic composition of atmospheric $\mathrm{N}_{2} \mathrm{O}$ back to 1800 A.D. from air trapped in snow at South Pole and the Greenland Ice Sheet Project II ice core, Global Biogeochem. Cycles, 16(4), 1129, doi:10.1029/ $2002 \mathrm{~GB} 001911$

Sowers, T., R. B. Alley, and J. Jubenville (2003), Ice core records of atmospheric $\mathrm{N}_{2} \mathrm{O}$ covering the last 106,000 years, Science, 301, 945-948.
Streets, D. G., et al. (2003), An inventory of gaseous and primary aerosol emissions in Asia in the year 2000, J. Geophys. Res., 108(D21), 8809, doi:10.1029/2002JD003093.

United Nations Department of Economic and Social Affairs (2003), World Population in 2300, New York.

U.S. Environmental Protection Agency (2004), Inventory of U.S. greenhouse gas emissions and sinks: 1990-2002, EPA Publ. 430-R-04-003, Washington, D. C. (Available at http://yosemite.epa.gov/oar/globalwarming.nsf/content/ResourceCenterPublicationsGHGEmissionsUSEmissionsInventory2004.html.)

Velthof, G. L., P. J. Kuikman, and O. Oenema (2003), Nitrous oxide emission from animal manures applied to soil under controlled conditions, Biol. Fertil. Soils, 37, 221-230.

Volk, C. M., et al. (1997), Evaluation of source gas lifetimes from stratospheric observations, J. Geophys. Res., 102, 25,543-25,564.

Wang, T., et al. (2003), Chemical characterization of the boundary layer outflow of air pollution to Hong Kong during February-April 2001, J. Geophys. Res., 108(D20), 8787, doi:10.1029/2002JD003272.

Wang, Y. X., M. B. McElroy, T. Wang, and P. I. Palmer (2004a), Asian emissions of $\mathrm{CO}$ and $\mathrm{NO}_{\mathrm{x}}$ : Constraints from aircraft and Chinese station data, J. Geophys. Res., 109, D24304, doi:10.1029/2004JD005250.

Wang, T., et al. (2004b), Relationships of trace gases and aerosols and the emission characteristics at Lin'an, a rural site in eastern China during spring 2001, J. Geophys. Res., 109, D19S05, doi:10.1029/2003JD004119.

Wrage, N., G. L. Velthof, M. L. van Beisichem, and O. Oenema (2001) Role of nitrifier denitrification in the production of nitrous oxide, Soil Biol. Biochem., 33, 1723-1732.

Yienger, J. J., and H. Levy II (1995),Empirical mode of global soil-biogenic $\mathrm{NO}_{\mathrm{x}}$ emissions, J. Geophys. Res., 100, 11,447-11,464.

M. B. McElroy and Y. X. Wang, Department of Earth and Planetary Sciences, Division of Engineering and Applied Sciences, Harvard University, 29 Oxford Street, Pierce Hall, Cambridge, MA 02138, USA. (mbm@io.harvard.edu) 


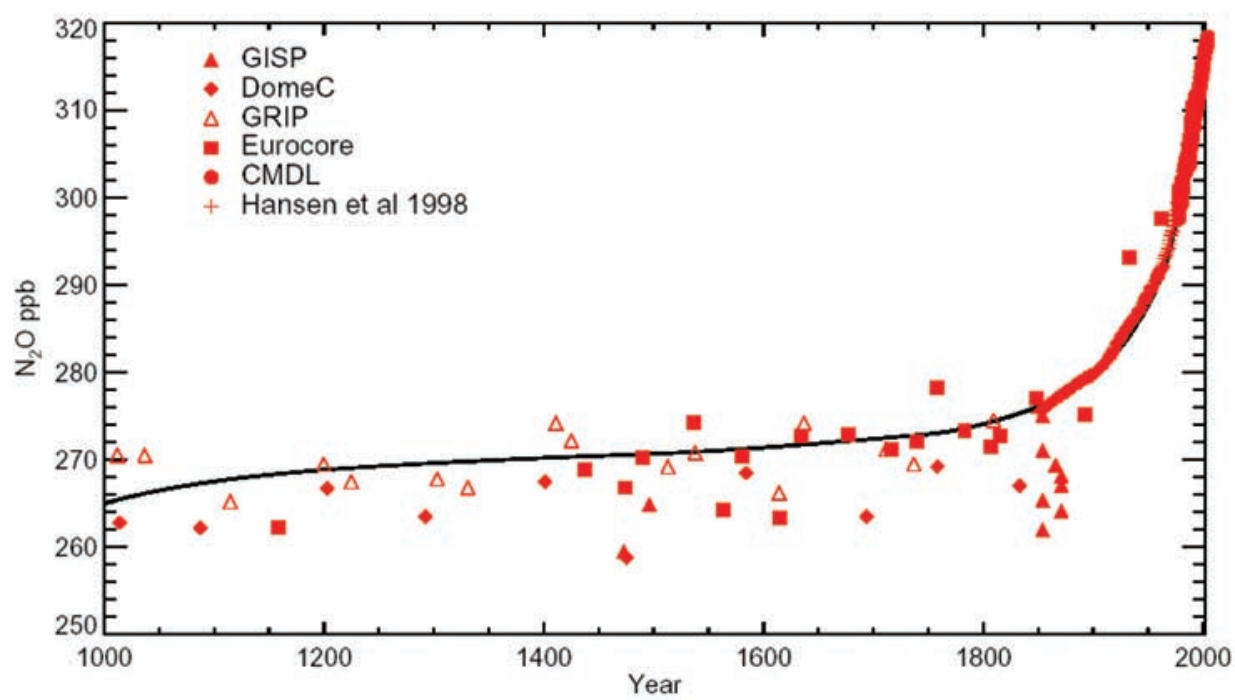

Figure 2. Comparison between observed (red symbols) and simulated (black line) atmospheric concentrations of $\mathrm{N}_{2} \mathrm{O}$ for the period 1000-2001. Observations are taken from ice core measurements from GISP II [Sowers et al., 2003], Eurocore and GRIP [Flückiger et al., 2000], the Climate Monitoring and Diagnostics Laboratory (CMDL), and composite data set from Hansen et al. [1998]. 